\title{
Peran Otoritas Jasa Keuangan (OJK) dalam Mengawasi Adanya Fraud dalam Bisnis Investasi dalam Perspektif Hukum Ekonomi Islam
}

\section{Fajar Tri Pamungkas, Ahmad Arif Zulfikar*}

Magister Hukum, Universitas Muhammadiyah Yogyakarta, Indonesia

*) Corresponding Email: ahmadarifzulfikar1@gmail.com

\section{INFO ARTIKEL}

Perjalanan Artikel:
Artikel Dikirimkan oleh
penulis: 05-08-20
Artikel Direview: $27-11-20$
Artikel Direvisi: $07-12-20$
Artikel Diterima atau
Dipublikasikan: 27-04-21
DOI:
https://doi.org/10.18196/JPH
K.V2I1.9507

\section{Pendahuluan}

Sebagai sebuah lembaga yang telah terbentuk, Otoritas Jasa Keuangan (OJK) bertujuan menjadi pengawas lembaga keuangan serta mempunyai kontribusi yang besar untuk mencegah serta menanggulangi permasalahan fraud pada bisnis investasi yang ada pada masyarakat. Pembentukan OJK bertujuan agar seluruh aktivitas pada sektor jasa keuangan dapat diselenggarakan dengan transparan, teratur, akuntabel dan adil, ataupun merealisasikan sistem keuangan yang stabil serta mempunyai keberlanjutan dalam pertumbuhannya. Selain itu, OJK juga dapat berfungsi memberi perlindungan terhadap kepentingan konsumen serta masyarakat, yang diimplementasikan dengan pengadaan sistem yang saling mendukung dengan semua 
aktivitas pada sektor jasa keuangan untuk mengawasi serta mengatur. ${ }^{1}$

Investasi sendiri berasal dari istilah invest yang artinya menanam ataupun melakukan investasi modal ataupun uang. ${ }^{2}$ Investasi pada umumnya dimaknai sebagai sebuah aktivitas yang dilaksanakan baik oleh seorang individu (natual person) ataupun badan hukum (yuridical person), pada rangka usaha peningkatan ataupun menjaga angka modalnya, baik yang berbentuk uang kas (cash money), perlengkapan (equipment), asset tidak beranjak, hak atas kekayaan intelektual, atau kemampuan. ${ }^{3}$

Pada dasarnya pemasukan bank dari angsuran mempunyai resiko yang lumayan besar sebab tidak seluruh pinjaman yang diserahkan pada warga melalui angsuran leluasa risiko. Firmansyah ${ }^{4}$ mengungkapkan, sebenarnya tidak semua pinjaman yang disalurkan kepada masyarakat tergolong sehat, melainkan termasuk pinjaman berkualitas kurang baik ataupun bermasalah. Tingkatan terbentuknya angsuran macet disebut dengan Non Performing Loan (NPL), sesuatu kejadian yang kerap terjalin di perbankan, sebab salah satu aktivitas perbankan yang terutama berasal dari angsuran. Bila angsuran macet besar, hingga menjadi permasalahan sungguh- sungguh yang mengusik profitabilitas bank serta berakhir pada pemberhentian operasional bank.

Praktek fraud dalam bisnis investasi serupa dengan pemodalan bawah tangan ataupun yang diketahui dengan pemodalan bodong dengan cara menjanjikan keuntungan tetap ataupun imbal hasil pada masing-masing individu tiap bulan walaupun perusahaan itu mengalami kerugian. Wujud penanaman model seperti itu benar-benar tidak wajar serta sifatnya sangat spekulatif dan berusaha untuk menjauhi ketentuan perbankan dalam menampung anggaran dari warga dalam wujud dana, dengan tidak meminta perizianan sebelumnya dari OJK yang menjadi lembaga paling tinggi untuk mengawasi maupun mengatur sektor jasa keuangan. ${ }^{5}$

Dari segi yuridis adanya fraud dalam bisnis investasi ada dua sisi yakni di satu sisi ada aspek hukum perdata sedangkan di sisi lain ada aspek hukum pidana. Keduanya mempunyai tujuan, karakteristik serta sifatnya berlawanan. Yang menjadi elemen terpenting dalam aspek hukum perdata yakni berdamainya pihak-pihak yang berselisih, dengan demikian terikat relasi hukum antar individu saja, sedangkan yang menjadi fokus utama pada aspek hukum pidana yakni kepentingan umum ataupun masyarakat secara umum. Dengan demikian, aspek hukum pidana sifatnya lebih memaksa, sebagai media untuk membuat jera pihak yang sudah merugikan pihak lain. Dengan demikian pada aturan yang melakukan pengaturan pada aspek

\footnotetext{
${ }^{1}$ Sutedi, A. (2014). Aspek Hukum Otoritas Jasa Keuangan. RAS.

${ }^{2}$ Hasan Shadily, dkk. (2011). Hukum Investasi dan Pasar Modal. Jakarta : Sinar Grafika, hal. 3.

${ }^{3}$ Harjono Dhaniswara, K. (2007). Hukum Penanaman Modal. Jakarta : PT Raja Grafindo Persada, hal. 10.

${ }^{4}$ Firmansyah, I. (2014). Determinant of non performing loan: The case of Islamic bank in Indonesia. Buletin Ekonomi Moneter dan Perbankan, 17(2), 241-258.

${ }^{5}$ Arsil. (2013). Menjerat Investasi Bodong dengan Tindak Pidana Perbankan. Jakarta: Lembaga Kajian \& Advokasi untuk Indenpedensi Peradilan.
} 
hukum perdata dicantumkan juga terkait aspek hukum pidana dengan takaran pengesahan dengan syarat atau tidak mutlak serta pengakuan tanpa syarat. Modus operandi fraud dalam bisnis investasi adalah sebuah perkara baru di dunia kriminalitas bisnis. Modus operandinya tidak dapat digolongkan menjadi kejahatan korporasi namun korporasi difungsikan sebagai wadah menampung hasil kejahatan. ${ }^{6}$

Diane Hasna Fadlia dan Yonanto menyebutkan bahwa meningkatnya pembohongan pemodalan ilegal diakibatkan minimnya wawasan mengenai zona keuangan serta kemauan warga untuk memperoleh profit yang besar. Banyak juga orang berpendidikan yang menjadi korban pembohongan permodalan. Oleh sebab itu, OJK sangat diperlukan untuk membagikan proteksi hukum pada penanam modal yang tidak jelas. Diane Hasna mengatakan bahwa proteksi hukum untuk penanam modal serta calon penanam modal dilakukan oleh OJK dengan melakukan dua aksi, yaitu aksi melindungi serta aksi represif. Aksi melindungi dicoba oleh OJK untuk menghindari warga melaksanakan pemodalan ilegal. Sedangkan aksi represif OJK dapat dicoba melalui aksi hukum kepada industri pemodalan delusif oleh regu pemodalan yang berjaga-jaga sebab proteksi hukum yang represif bermaksud untuk menuntaskan perselisihan.

Sebagai lembaga negara yang mengadakan sistem untuk mengawasi serta mengatur melalui integrasinya pada semua aktivitas dalam sektor jasa keuangan, yang bebas dari pihak lain serta berdiri sendiri, Otoritas Jasa Keuangan (OJK) memiliki kontribusi yang penting untuk melindungi hukum penanam modal pada implementasi adanya fraud yang kini tengah berkembang di Indonesia. Dengan tidak mendahulukan perizinan dari OJK yang menjadi lembaga tinggi dalam mengawasi serta mengatur sektor jasa keuangan. Berkaitan dengan keberadaan fraud dalam bisnis penanaman modal yang diselenggarakan dengan cara menerapkan pengumpulan dana masyarakat secara umum dan melakukan penyimpangan bahkan menjauh dari peraturan perbankan, merupakan aktivitas yang memanfaatkan fasilitas umum dalam melaksanakan aktivitas bisnisnya.

Oleh karenanya dibutuhkan adanya peninjauan wewenang yang OJK miliki untuk melindungi masyarakat terhadap adanya fraud dalam bisnis investasi, praktik moral hazard terkait adanya fraud dalam bisnis investasi terjadi karena sistem lembaga keuangan yang lemah dalam mengawasi aktivitas keuangan, yang ditimbulkan sejumlah faktor, yakni : (a) sistem arsitektur untuk mengawasi keuangan Indonesia yang lemah; (b) antar lembaga yang mengawasi keuangan tidak bertukar informasi; (c) antar lembaga yang mengawasi keuangan terdapat keegoan yang tinggi. ${ }^{7}$

${ }^{6}$ Atmasasmita, Romli. (2010). Globalisasi \& Kejahatan Bisnis. Jakarta: Prenamedia Grup. Cet I, h. 38.

7 Hermansyah. (2005). Hukum Perbankan Nasional Indonesia. Jakarta: Kencana Prenada Media Group, cet-1, hal. 125 . 
Berdasarkan pemaparan diatas, maka penulis tertarik untuk mengetahui kontribusi Otoritas Jasa Keuangan (OJK) untuk mengawasi adanya fraud pada bisnis investasi dalam perspektif hukum ekonomi Islam. Tujuan penyusunan artikel ini adalah untuk menganalisis kedudukan OJK dalam memantau terdapatnya unsur fraud di bidang usaha pemodalan dalam perspektif hukum ekonomi Islam.

\section{Metodologi}

\subsection{Jenis Penelitian}

Pada studi ini, metode yang digunakan yaitu studi hukum normatif. Penelitian hukum normatif riset pustaka ataupun studi fakta, merupakan penelitian yang dicoba ataupun tertuju pada peraturan tercatat ataupun disebut informasi inferior. ${ }^{8}$ Cakupan studi hukum normatif yakni sistematika hukum, studi pada asas-asas hukum, sinkronisasi hukum secara horizontal maupun vertikal supaya tercipta keselarasan aturan perundang-undangan tersebut berdasarkan hirarki perundang-undangan agar tidak saling terjadi pertentangan, dan perbandingan hukum.

\subsection{Spesifikasi Penelitian}

Spesifikasi riset yang digunakan pada studi ini yaitu deskriptif analisis dalam bentuk penjelasan secara rinci serta terkalkulasi yang dapat dianalisa melalui sebuah norma hukum yang sedang berjalan.

\subsection{Jenis dan Sumber Hukum}

Adapun sumber hukum yang digunakan pada riset ini ialah materi hukum inferior. Materi hukum inferior ialah materi- materi yang diterima dari buku- buku, seperti materi yang memenuhi pangkal materi hukum primer. Sumber bahan hukum merupakan data-data yang didapatkan melalui pengkajian pustaka, misalnya hasil studi, buku-buku ilmiah, dan lainnya. ${ }^{9}$ Bahan hukum sekunder didapatkan dari artikel-artikel di web, literatur, serta pemaparan peraturan undang-undang dan pasal-pasal.

\subsection{Analisis Bahan Hukum.}

Pada studi ini, data dianalisis secara kualitatif. Data sekunder yang didapatkan dianalisis secara kualitatif dalam menjawab rumusan masalah pada studi ini. Setelah bahan penelitian terkumpul, maka bahan hukum dianalisis untuk merumuskan kesimpulan. Teknik analisis bahan hukum yang digunakan yaitu metode Content Analysis. Arsip maupun dokumen yang dianalisis pada analisis bahan hukum jenis tersebut dikenal juga dengan istilah "teks". Metode analisis yang integratif serta secara konseptual berdasarkan Content analysis condong mengarah pada identifikasi, penemuan, analisa serta pengolahan bahan hukum dalam

8 Arliman, L. (2018). Peranan Metodologi Penelitian Hukum Di Dalam Perkembangan Ilmu Hukum Di Indonesia. Soumatera Law Review, 1(1), 112-132.

${ }^{9}$ Marzuki. (1983). Metodologi Riset, PT Hanindita Offset, Yogyakarta, hal. 56. 
pemahaman signifikasi, relevansi serta maknanya. ${ }^{10}$

\section{Analisis dan Hasil}

\subsection{Wewenang Otoritas Jasa Keuangan dalam Mengawasi Investasi}

Pembentukan OJK muncul karena adanya keprihatinan berbagai pihak terkait pengawasan Bank Indonesia. Kerangka balik terjadinya OJK terdiri dari 3 perihal, yaitu kemajuan pabrik pelayanan keuangan di Indonesia, kasus rute sektoral di aspek pelayanan keuangan, serta mandat UU No. 3 Tahun 2004 mengenai Bank Indonesia (Pasal 34 ayat (1)) yang menyatakan bahwa: "Tugas pengawasan bank akan dilakukan oleh lembaga pengawas sektor jasa keuangan yang independen dan dibentuk dengan undang-undang". Keadaan Darurat yang melanda Indonesia pada tahun 1997- 1998 menimbulkan banyak bank ambruk, alhasil banyak yang mempersoalkan pengawasan bank oleh Bank Indonesia. Kelemahan kelembagaan serta pengaturan yang tidak mendukung kesehatan dunia perbankan, diharapkan bisa diperbaiki guna menghasilkan kerangka sistem finansial yang lebih fleksibel. Pembaruan pada aspek hukum perbankan diharapkan jadi obat penyembuh darurat, dan sekaligus sebagai penangkal di era depan. ${ }^{11}$

Lahirnya OJK diharapkan mampu mewujudkan pengawasan di bidang jasa keuangan yang efektif dan terintegrasi, pengawasan yang lebih mudah, dan koordinasi yang lebih mudah sehingga semua kegiatan di bidang jasa keuangan terselenggara secara tertib, adil, transparan, dan akuntabel yang mampu mewujudkan sistem keuangan yang tumbuh secara berkelanjutan dan stabil serta mampu melindungi kepentingan konsumen dan masyarakat. Pengawasan sektor keuangan Indonesia, termasuk Pasar Modal dilakukan oleh Otoritas Jasa Keuangan. ${ }^{12}$

Menurut Pasal 6 UU No 21 Tahun 2011, tugas pokok OJK adalah mengatur serta mengawasi aktivitas pelayanan keuangan di zona perbankan, pasar modal, zona perasuransian, anggaran pensiun, badan finansial, serta zona pelayanan finansial yang lain. Bersumber pada determinasi Pasal 69 ayat (1) huruf (A) UU No. No. 21 Tahun 2011 menerangkan kalau kewajiban Bank Indonesia dalam menata serta memantau bank yang hendak dialihkan ke OJK merupakan kewajiban pengaturan serta pengawasan terpaut kredensial yang cermat, sebaliknya Bank Indonesia sedang mempunyai kewajiban pengaturan perbankan terpaut dengan persediaan totalitas.

Terpaut proteksi pelanggan yang juga menjadi kewajiban OJK, ada 3 artikel di OJK yang menerangkan peranan OJK mencegah pelanggan badan pelayanan

10 Bungin, B. (2019). Metodologi Penelitian Kualitatif: Aktualisasi Metodologis Ke Arah Ragam Varian Kontemporer. Jakarta: PT. RajaGrafindo Persada, hal. 203.

11 Sutedi, A. Op.Cit., hal. 36.

12 Haikal, S. (2019). Weak, Permissive and Error-Tolerant Supervision: Starting From Correction Habits to Acquit et de Charge Trap As an Entrance to Capital Market Scandal. Asia Pacific Fraud Journal, 4(1), 78-95. 
keuangan, ialah Pasal 28 (aksi penangkalan kehilangan pelanggan serta warga), Pasal 30 (advokasi hukum), serta Pasal 29 (layanan pengaduan Pelanggan).

\subsubsection{Pengaturan dan Pengawasan di Sektor Perbankan}

Seperti yang tertera pada Pasal 6 huruf (a) UU No. 21 Tahun 2011, tugas dalam mengawasi serta mengatur pada sektor perbankan sebagaimana di maksud pada Pasal 6 huruf (a) UU No. 21 Tahun 2011, bisa dilaksanakan melalui wewenangseperti:

1) Pengaturan serta pengawasan mengenai kelembagaan bank yang meliputi: a) Melakukan proses izin dalam membuka kantor bank, hak milik, rencana kerja, anggaran dasar, akuisisi serta konsolidasi bank, merger, mencabut, izin usaha bank juga dalam mendirikan bank; dan b) Kegiatan usaha bank, diantaranya yakni aktivitas sektor jasa, proses menyediakan dana, produk hibridasi, serta sumber dana.

2) Proses mengawasi serta mengatur terkait kesehatan bank yang termasuk di dalamnya yaitu: a) Likuiditas, rentabilitas, solvabilitas, kualitas asset, rasio kecukupan modal minimum, batas maksimal dalam memberikan kredit, rasio pinjaman terhadap simpanan dan pencadangan bank; b) Laporan bank yang terkait denan kesehatan dan kinerja bank; c) Sistem informasi debitur; d) Pengujian kredit (credit testing); e) Standar akuntansi bank.

3) Proses mengatur serta mengawasi terkait aspek kehati-hatian, yang mencakup: a)Manajemen risiko; b) Tata kelola bank; c) Prinsip mengenal nasabah dan anti pencucian uang; d) Pencegahan pembiayaan terorisme dan kejahatan perbankan

4) Pemeriksaan bank

\subsubsection{Pengaturan serta Pengawasan di Sektor Keuangan}

Pelaksanakan kewajiban pengawasan begitu juga diartikan dalam pasal 6, OJK mempunyai wewenang yaitu: a) Memastikan kebijaksanaan operasioanal pengawasan kepada badan pelayanan keuangan; b) Melaksanakan pengawasan pada penerapan kewajiban pengawasan yang dilaksanakan oleh kepala Eksekutif; c) Melangsungkan aksi ialah mengecek, memeriksa, mencegah pelanggan, memantau dan yang lain kepada badan finansial pelakon, ataupun yang mendukung kegiatan lemaga pelayanan keuangan seperti yang tercetak pada ketentuan hukum di zona pelayanan keuangan; d) Membagikan perintah tercatat pada badan pelayanan keuangan ataupun pihak tertentu; e) Melaksanakan penunjukan pengelola statute; f) Memastikan eksploitasi yang mengatur statute; g) Memastikan ganjaran administratif pada pihak yang melanggar peraturan perundang- undangan di zona pelayanan keuangan; h) Membagikan ataupun mencabuti izin usaha, izin orang perseorangan, efektifnya pernyataan pendaftaran, surat tanda terdaftar, persetujuan melakukan kegiatan usaha, pengesahan, persetujuan atau penetapan pembuabaran dan penetapan lain. 
Badan pelayanan keuangan yang diawasi OJK tidak melaksanakan pelanggaran. Bila pelanggaran dilakukan oleh badan pelayanan keuangan, OJK akan membagikan ganjaran cocok dengan determinasi peraturan perundang-undangan ${ }^{13}$. Tipe ganjaran yang ditawarkan bermacam- macam. Sesuai dengan tingkatan pelanggaran yang dilakukan. Bila pelanggarannya kecil maka hanya dengan catatan peringatan, tetapi bila mudarat konsumen serta pihak lain yang dirasa parah, OJK berkuasa mencabut izin niaga.

Setelah berlakunya serta disetujui UU OJK, alhasil OJK mengambil alih pengawasan di zona pelayanan keuangan yang tadinya dipegang oleh Bank Indonesia (BI) serta Tubuh Pengawas Badan Keuangan- Pasar Uang (Bapepam- Lk). Perihal ini bermaksud agar pengawasan menjadi terintegrasi dan menyeluruh. ${ }^{14}$ Terkait pandangan kedaulatan wewenang dalam peraturan perundang-undangan yang diatur dalam UU OJK, dengan cara nyata serta jelas sudah dibangun OJK serta didasarkan pada prinsip-prinsip aturan mengurus yang mencakup kedaulatan, akuntabilitas, responsibilitas, serta kejernihan. OJK ditatap bagaikan tubuh hukum yang bebas dalam melaksanakan kewajiban serta wewenangnya tanpa campur tangan pihak lain ataupun lembaga negara lainnya, sebagaimana diatur dalam Pasal 2 ayat (2) UU OJK.

Menurut Zain Arefin Mukhtar, independensi OJK terkait dengan beberapa hal: pertama, independensi terkait pemberhentian badan yayasan yang hanya bisa didasarkan pada alibi yang diatur dalam UU mengenai pembuatan yayasan. Kedua, sifat seorang freelancer juga terbagi menjadi 3 (tiga) perihal: Awal, kepemimpinan badan secara kolegial, dan bukan cuma satu atasan. Kepemimpinan kolegial ini bermanfaat Ketika akan membuat ketetapan secara mandiri dan menjauhkan kemungkinan politisasi ketetapan dengan cara pemilahan keahlian. Kedua, kepemimpinan ini tidak patuh pada pengawasan partai politik. Ketiga, kehidupan kepemimpinan kolegial ini tidak berakhir serentak, melainkan secara bergiliran. ${ }^{15}$

\subsection{Fraud dalam Bisnis Investasi}

Istilah investasi diadopsi dari bahasa Inggris yakni investment. Sebagai kata yang merupakan asal kata investmen, kata invest mempunyai makna menanam. ${ }^{16}$ Sederhananya investasi bisa dimaknai sebagai aktivitas yang mempunyai tujuan dalam pengembangan harta, disamping hal tersebut investasi juga adalah sebuah komitmen dalam sejumlah pada beberapa dana maupun sumber daya yang lain yang

\footnotetext{
13 Undang-undang No. 21 Tahun 2011 Tentang Otoritas Jasa Keuangan.

14 Haryani, W. S. (2012). Independensi Otoritas Jasa Keuangan dalam Persepektif Undang Undang Nomor 21 Tahun 2011 tentang Otoritas Jasa Keuangan. Jurnal Legislasi Indonesia, 9(3).

15 Mochtar, Z. A., \& Satriawan, I. (2008). Sistem Seleksi Komisioner State Auxiliary Bodies (Suatu Catatan Analisis Komparatif). Jurnal Konstitusi Pusako Universitas Andalas, 1(1), 85-106.

16 Wijaya, R. F. (2014). Negative Investement: Kiat Menghindari Kejahatan dalam Dunia Investasi. Jakarta : PT. Elex Media Komputindo.
} 
dilaksanakan di masa sekarang yang bertujuan untuk memperoleh beberapa keuntungan di masa depan. ${ }^{17}$

Berdasarkan pendapat Indah Yuliana yang diambil dari opini Iwan Pantjowinoto memberikan definisi investasi yakni merupakan penempatan maupun penanaman aset, baik dalam bentuk dana mauupun harta, terhadap sebuah hal yang diinginkan nantinya memberi hasil perolehan maupun peningkatan nilai di waktu yang akan datang. Investasi merupakan sebuah kata dengan sejumlah definisi yang berkaitan dengan ekonomi serta finansial, kata itu berhubungan melalui akumulasi sebuah bentuk aktiva dengan suatu harapan, memperoleh profit di waktu yang akan datang. Berlandaskan pada filosofi ekonomi, pemodalan yang maksudnya pembelian (serta berarti juga penciptaan) dari kapital atau modal beberapa barang yang dimanfaatkan dalam penciptaan selanjutnya. Di sisi lain pada hubungannya dengan finansial, investasi artinya membeli saham maupun bentuk finansial yang lain maupun aktiva kertas, seperti investasi ekuitas/saham, valuta asing maupun obligasi. Investasi tersebut bisa memberikan arus kas di waktu yang akan datang serta kemungkinan nantinya mereduksi maupun memberi tambahan pada nilai. Pada dasarnya, investasi merupakan uang yang disisihkan di masa kini, kemudian diletakkan supaya memperoleh suatu hal di waktu yang akan datang, yang diharapkan lebih besar daripada saat ini. Dengan demikian bisa diambil kesumpulan bahwa investasi pada umumnya merupakan aktivitas pengalokasian dana supaya memperoleh nilai lebih maupun profit di masa depan (yang akan datang). ${ }^{18}$

Pada sistem pemodalan diketahui juga sebutan Pemodalan bawah tangan ataupun pemodalan bodong. Rendahnya wawasan terkait investasi menjadikan seorang individu begitu mudahnya melakukan investasi pada instrument serta perusahaan yang salah.

Industri pemodalan bodong diketahui apabila para investor mendapatkan return yang sudah dijanjikan, orang-orang tersebut condong melakukan investasi kembali dari keuntungan uang itu. Seperti mengundang keluarga, teman, maupun kerabat untuk berinvestasi. Biasanya perusahaan investasi palsu menunjukkan profil perusahaan uang terlihat profesional dan jujur tentang penarikan "calon korban". Namun jika dikaji dengan seksama, banyak terdapat penyimpangan, seperti ketidakjelasan pengelolaan manajemen, kinerja investasi, atau kurangnya laporan keuangan yang lengkap dan diaudit . ${ }^{19}$

\footnotetext{
17 Hayati, M. Investasi dalam Perspektif Ekonomi Islam. Jurnal Ekonomi dan Bisnis Islam, hal. 67.

${ }^{18}$ Yuliana, I. (2010). Investasi Produk Keuangan Syariah. Malang : UIN Malika Press, hal. 3.

${ }^{19}$ Ibid. hal. 105.
} 
Hukum investasi dalam hal ini lebih erat kaitannya dengan aturan yang didasarkan pada hukum perbankan yang secara eksplisit mengancam penjara dan denda terhadap pelaku investasi penindas, yang mana ancaman hukum terhadap mereka yang melakukan kegiatan usaha tanpa izin penggalangan dana masyarakat. ${ }^{20}$

Bentuk fraud dalam bisnis investasi mempunyai karakter dalam produk yang ditawarkan, antara lain:

1. Return ataupun profit yang ditawarkan sangat besar (acapkali tidak masuk akal) ataupun dengan jumlah khusus, produk pemodalan ditawarkan dengan akad dipastikan dengan instrumen khusus, semacam kencana serta rekening giro, ataupun dipastikan oleh pihak khusus semacam penguasa, bank, dan lain- lain. Dengan memakai nama- nama industri besar dengan cara bawah tangan untuk memastikan calon penanam modal, anggaran penduduk tidak disimpan di rekening terpisah (segregated account) sehingga mudah digunakan dengan cara yang tidak bertanggung jawab. ${ }^{21}$

2. Bentuk biasa yang didatangkan dalam pemodalan bawah tangan merupakan dalam wujud produk pemasukan senantiasa, sebab produk ini menawarkan pengembalian yang dipastikan dengan cara teratur serta tidak hendak terbawabawa oleh resiko pergerakan harga di pasar, dana yang mendekati dengan produk perbankan (dana ataupun simpanan), dimana dalam sebagian permasalahan. Berbentuk delivery instruksi (D atau $\mathrm{O}$ ) ataupun pesan bernilai yang diterbitkan oleh sesuatu industri, modal ventura, di mana akad untuk menaruh anggaran yang digabungkan dari warga di lebih dari satu instrumen finansial ataupun di zona riil, itu merupakan program pemodalan online lewat Internet, yang menjanjikan pengembalian anggaran pemodalan dengan cara tertib. Sementara itu, uang penanam modal A digunakan untuk melunasi bunga pada penanam modal B, penanam modal B digunakan untuk melunasi return pada penanam modal C, serta berikutnya. Sampai sesuatu dikala belum terdapat penanam modal terkini yang menancapkan uangnya, ataupun anggaran yang ada tidak memenuhi.

\subsection{Peran Otoritas Jasa Keuangan (OJK) Dalam Mengawasi Adanya Fraud pada Bisnis Investasi dalam Perspektif Ekonomi Islam}

Otoritas Jasa Keuangan (OJK) hadir sebagai pengawas pelayanan keuangan di Indonesia, seperti pengawasan di perbankan, pasar modal, reksa dana, industri pembiayaan, anggaran pensiun serta asuransi. Menurut Sundari, Pada mulanya kehadiran dibentuknya lembaga Otoritas Jasa Keuangan (OJK) diibaratkan seperti

\footnotetext{
${ }^{20}$ Tarina, D. D. Y., \& Hutabarat, S. M. D. (2020). Supervision of Investment Companies in the Prevention of Illegal Investment Practices. International Journal of Multicultural and Multireligious Understanding, 7(4), 215-224.

${ }^{21}$ Otoritas Jasa Keuangan. (2016). Buku Saku Otoritas Jasa Keuangan. Jakarta :OJK, hal. 322-323.
} 
lembaga independen pengawas zona finansial di Indonesia, yang mengawasi seluruh aktifitas transaksi keuangan baik bank maupun non bank.22

Pasal 1 UU No 21 Tahun 2011 berbunyi:

“Otoritas Jasa Keuangan, yang selanjutnya disingkat dengan OJK, adalah lembaga yang independen dan bebas dari campur tangan pihak lain, yang mempunyai fungsi, tugas, dan wewenang pengaturan, pengawasan, pemeriksaan, dan penyidikan sebagaimana dimaksud dalam Undang - Undang ini".

Oleh sebab itu, pendirian OJK diharapkan bisa menghasilkan metode koordinasi yang lebih efektif dalam menanggulangi kasus yang mencuat di sistem keuangan di Indonesia. Dengan begitu, bisa lebih menjamin kemapanan sistem keuangan dan pengaturan serta pengawasan yang lebih terintegrasi. ${ }^{23}$

Menurut UU No. 21 Tahun 2011, Otoritas Jasa Keuangan (OJK) merupakan lembaga pengawas yang membawahi pelayanan keuangan seperti perbankan, pasar modal, reksa anggaran, industri pembiayaan, anggaran pensiun serta asuransi. OJK merupakan lembaga yang mempunyai independensi serta bebas dari campur tangan pihak lain, dengan kewajiban serta wewenang menata, memantau, mengecek, serta menyelidiki transaksi keuangan bank maupun non bank di Indonesia. Terdapat sebagian figur warga yang menyuarakan pandangannya terhadap OJK, antara lain:

1. Agus Martowardojo menyatakan bahwa pembentukan OJK dibutuhkan untuk menuntaskan kerumitan finansial garis besar dari bahaya darurat. Di bagian lain, pembuatan OJK ialah komitmen penguasa untuk melaksanakan pembaruan area finansial di Indonesia.

2. Fuad Rahmany menyatakan kalau OJK hendak melenyapkan penyalahgunaan kewenangan (abuse of power) yang potensial timbul, mengingat dalam OJK, kewenangan melakukan pengawasan serta membuat pengaturan dibuat terpisah.

3. Muliaman D Hadad menyatakan bahwa terdapat 4 pilar zona finansial garis besar yang jadi tugas OJK. Pertama, kerangka kebijaksanaan yang kokoh untuk mengatasi keadaan darurat. Kedua, perencanaan pernyataan kepada lembagalembaga finansial yang ditengarai dapat berakibat sistematik. Ketiga, badan finansial membuat pesan amanat jika terjalin kehancuran, serta keempat, kejernihan yang wajib dilindungi.

Nilai-nilai strategis OJK antara lain:

1. Integritas

22 Sundari, S. (2011). Laporan Kompendium Hukum Bidang Perbankan. Jakarta: Kementrian Hukum dan HAM RI, hal. 44.

${ }^{23}$ Sinaga, R. D., Nasution, B., \& Siregar, M. (2013). Sistem Koordinasi antara Bank Indonesia dan Otoritas Jasa Keuangan dalam Pengawasan Bank setelah Lahirnya Undang-Undang Nomor 21 Tahun 2011 Tentang Otoritas Jasa Keuangan. Transparency Journal of Economic Law, 1(2), 14694. 
Berperan adil, seimbang, serta tidak berubah-ubah, sesuai dengan kode etik serta kebijaksanaan badan dengan menjunjung besar kejujuran serta komitmen. Sikap penting yang harus dimilili yaitu jujur dan di yakin, bijaksana, tidak berubah-ubah dalam percakapan serta perbuatan.

2. Profesionalisme

Bertugas dengan penuh tanggung jawab bersumber pada kompetensi yang besar untuk menyakini kemampuan terbaik berlatih berkepanjangan, membagikan jasa prima pada pengelola kebutuhan, dan berkomitmen kepada hasil kegiatan yang berkualitas.

3. Sinergi

Bekerja sama dengan semua pengelola kebutuhan baik dalam ataupun eksternal dengan cara produktif serta bermutu membuat rasa silih yakin, berbicara dengan cara efisien, dan mencari pemecahan terbaik untuk mendapatkan angka tambah.

4. Inklusif

Terbuka serta menyambut keanekaan pengelola kebutuhan dan meluaskan peluang serta akses warga kepada pabrik finansial menghormati keberagaman, berperilaku seimbang, partisipatif, kontributif, fasilitatif, serta edukatif.

5. Visioner

Mempunyai pengetahuan yang besar serta sanggup memandang ke depan (forward looking) dan bisa berfikir di luar kerutinan (out of the box thinking) mencari serta meningkatkan rancangan serta ilham terkini, memandang jauh kedepan, dan menginspirasi serta mensupport perubahan. ${ }^{24}$

Dalam melaksanakan aktivitas di pasar modal, setiap orang wajib mempunyai salah satu akta yang terdapat, ialah:

a. Wakil Pialang dan Dealer (WPPE), yaitu mereka yang bekerja di sekuritas dan menjadi penjual saham yang harus dipunyai seseorang.

b. Agent Representative (WPEE), untuk bekerja dalam mengelola sekuritas hutang atau penerbitan saham utama

c. Perwakilan Manajer Investasi (WMI), untuk bekerja di perusahaan yang mengelola dana klien yang dikumpulkan seperti reksa dana.

Salah satu fungsi, tugas, wewenang, dan pengawasan dari OJK yaitu melaksanakan pengawasan kepada Badan Finansial Non Bank. OJK memiliki wewenang dalam melakukan penguatan hukum sebagaiman disebutkan dalam Pasal 49 UU OJK. OJK dapat merekrut interogator dari Petugas Kepolisian serta Penyidik Karyawan Negara Sipil PPNS) dari lembaga lain. Karwayan OJK adalah bukan berkedudukan sebagai PNS, dikarenakan OJK secara kelembagaan berada di luar lingkaran penguasa, maka tidak ada PPNS di lingkungan OJK yang melakukan penyidikan. ${ }^{25}$ Krisis keuangan yang menyerang Indonesia pada era itu membuktikan

${ }^{24}$ Hadad, M. D. (2016), Laporan Kinerja Otoritas Jasa Keuangan. Jakarta : OJK, hal. 13.

${ }^{25}$ Juliana, M. D. (2015). Kewenangan Otoritas Jasa Keuangan Mengenai Perlindungan Hukum 
terdapatnya kelemahan dalam sistem pengawasan perbankan oleh bank esensial. Penguasa serta DPR setelah itu membenarkan dalam menghubungkan wewenang kebijaksanaan perbankan besar serta mikro, di mana bank esensial mengawasi perbankan besar, sebaliknya perbankan mikro diserahkan pada sesuatu Lembaga Pengawas Jasa Keuangan (LPJK). ${ }^{26}$

OJK sebagai lembaga yang bebas serta independen dari campur tangan pihak ketiga, memiliki tujuan serta wewenang untuk menata, memantau, mengecek dan menyelidiki. Badan ini dibangun dengan tujuan untuk melakukan seluruh aktivitas di aspek pelayanan keuangan dengan cara teratur, seimbang, tembus pandang, serta akuntabel; mampu menciptakan sistem finansial yang berkembang dengan cara berkepanjangan serta normal; mampu mencegah kebutuhan pelanggan serta warga. OJK mengemban tujuan untuk menyelenggarakan sistem pengaturan serta pengawasan yang berintegrasi untuk semua aktivitas di aspek pelayanan keuangan dan aspek perbankan; pasar modal; serta pelayanan keuangan di zona asuransi, anggaran pensiun, badan pembiayaan serta badan pelayanan keuangan yang lain. ${ }^{27}$

Pembentukan OJK bertujuan agar semua aktivitas di aspek pelayanan keuangan dilaksanakan dengan cara teratur, seimbang, transparan, serta akuntabel, alhasil sanggup menciptakan sistem finansial yang berkembang dengan cara berkesinambungan serta normal. Tidak takluk berartinya, seluruh kegiatan di zona pelayanan keuangan sanggup mencegah kebutuhan pelanggan serta warga. Tujuan OJK merupakan menata serta memantau 3 zona pelayanan keuangan, yaitu zona perbankan, zona pasar modal, zona perasuransian, anggaran pensiun, badan pembiayaan serta badan pelayanan keuangan yang lain. Di aspek perbankan spesialnya, OJK mempunyai wewenang untuk menata serta memantau kelembagaan perbankan, pandangan kesehatan perbankan serta pandangan kehati- hatian perbankan, dan melaksanakan pengecekan kepada bank. Dengan begitu, publikasi permisi pendirian bank, dan pembatalan permisi upaya bank menjadi wewenang OJK.

OJK berhak melaksanakan pengawasan, pengecekan, investigasi, proteksi pelanggan, serta aksi lain kepada badan pelayanan keuangan, pelaku ataupun aktivitas pelayanan keuangan pendukung begitu juga diatur dalam peraturan perundang- undangan di aspek pelayanan keuangan untuk ketiga zona pelayanan keuangan itu. OJK pula diberi wewenang untuk membagikan ganjaran administratif pada pihak yang melanggar peraturan perundang- undangan di zona pelayanan keuangan. Wewenang OJK yang lain yaitu membagikan serta ataupun mencabut

Bagi Investor Terhadap Tindakan Tippee Yang Melakukan Insider Trading Dalam Perdagangan Saham. Jurnal Magister Hukum Udayana, 4(2).

26 Mustaqim, A. H. (2010). Otoritas Jasa Keuangan Sebagai Solusi Sistem Ekonomi Nasional. Jurnal Perspektif, 8(1).

${ }^{27}$ Samsul, I. (2016). Perlindungan Konsumen Jasa Keuangan Pasca Pembentukan Otoritas Jasa Keuangan (OJK). Negara Hukum: Membangun Hukum untuk Keadilan. 
permisi kerja, izin perorangan, data pendaftaran efektif, sertifikat pendaftaran, persetujuan untuk melakukan kegiatan komersial, mengesahkan, menyetujui, atau menentukan solusi dan ketentuan lain begitu juga diatur dalam peraturan perundang- undangan di aspek pelayanan keuangan.

Pendirian OJK sebenarnya telah dirancang sejak tahun 1999, dimana Pasal 34 UU No. 23 Tahun 1999 hal Bank Indonesia sudah menginstruksikan pembuatan Badan Pengawas Pelayanan keuangan (LPJK) yang memiliki guna memantau seluruh kegiatan di tiap zona pelayanan keuangan di Indonesia. Jadi perbuatan lanjut Pasal 34 UU No. 23 Tahun 1999, dibuat OJK dengan UU No. 21 Tahun 2011 hal OJK. Bersumber pada UU, Otoritas Pelayanan Keuangan mempunyai fungsi menyelenggarakan sistem pengaturan serta pengawasan yang berintegrasi pada seluruh kegiatan di dalam sektor Jasa Keuangan di Indonesia.

Pembentukan UU OJK itu searah dengan opini Ann Seidman, Robert B. Siedman serta Nalin Abeyesekere yang menyampaikan kalau pembuatan UU merupakan perlengkapan penting penguasa melakukan pergantian pada badan. Pembuatan Daulat Pelayanan keuangan merupakan wujud ataupun bentuk "pengawasan tunggal tertata" dimana pengaturan sektor finansial diserahkan pada satu otoritas yang terpisah dari bank sentral. Daulat ini bertanggung jawab atas seluruh pasar finansial serta pialang, dan mempunyai kewajiban untuk menggapai seluruh tujuan pengaturan (kemantapan, kejernihan, serta perlindungan investor).

OJK memiliki kewenangan untuk mengambil langkah-langkah penangkalan kehilangan untuk pelanggan serta warga, antara lain: membagikan data serta bimbingan pada warga mengenai karakter zona, pelayanan, serta produk pelayanan keuangan; memohon badan pelayanan keuangan untuk mengakhiri kegiatannya jika aktivitas itu berpotensi merugikan warga; dan aksi lain yang dianggap cocok dengan determinasi peraturan perundang- undangan di aspek pelayanan keuangan. Tidak hanya melaksanakan aksi melindungi, OJK juga membagikan layanan aduan pelanggan serta diberdayakan untuk membagikan advokasi hukum.

Langkah Indonesia menciptakan regulasi pelayanan keuangan yang berintegrasi sudah lama ingin dilakukan seperti negara-negara lain yang lebih dahulu melaksanakannya. Norwegia misalnya, sejak 1986 sudah mendirikan Kredittilsynet yang berperan sebagai regulator untuk aktivitas perbankan, pemodalan nonperbankan, asuransi, real estate, serta audit. Pada tahun 2000, badan ini didiberikan wewenang pengawasan atas Pasar uang Dampak Oslo. Di Swedia dibuat badan serupa pada tahun 1991 bernama Finansipektionen, begitu juga Korea yang mempunyai Financial Supervision Services (FSS). Pryault berkata keuntungan dari pembuatan unified regulator antara lain:

1. Mengkoordinasikan, menyatukan, dan merasionalisasi prinsip, ketentuan, serta prinsip yang dikeluarkan oleh bermacam tubuh pengatur ataupun yang tercantum dalam peraturan perundang- undangan, dengan memikirkan hal 
serupa yang cocok untuk satu tipe bidang usaha, pasar ataupun klien belum pasti benar untuk yang lain.

2. Operasi tunggal untuk berbagai kewajiban seperti perizinan, standar serta database yang serupa.

3. Pendekatan yang tidak berubah- ubah serta koheren ataupun pengawasan berplatform resiko dalam pabrik pelayanan keuangan, yang membolehkan peruntukan sumber daya serta bobot yang dialokasikan ke seluruh industri dalam pabrik yang diatur dengan cara lebih efisien serta berdaya guna bersumber pada resiko yang bisa jadi dialami pelanggan pelayanan keuangan.

4. Pendekatan yang tidak berubah- ubah serta koheren untuk penguatan serta patuh, namun pada saat yang sama juga mencermati kemungkinan ataupun keinginan untuk diferensiasi.

5. Selain satu regulator, terdapat juga satu skema pengaduan dan kompensasi konsumen.

OJK juga k berperan sebagai pengawas pabrik Perbankan. Pasal 6 UU OJK memutuskan kalau fungsi pengaturan serta pengawasan pada seluruh kegiatan di sesuatu zona Pelayanan keuangan dilaksanakan oleh OJK. Dengan cara filosofi, terdapat 2 gerakan pandangan dalam perihal ini Pengawasan Zona Pelayanan keuangan. Di pihak lain, terdapat arus masuk yang melaporkan kalau pengawasan berintegrasi atas semua aktivitas di zona pelayanan keuangan wajib dicoba oleh satu badan. Di bagian lain, ada yang beranggapan kalau pengawasan terhadap zona pelayanan keuangan lebih pas dicoba oleh sebagian institusi.

Peraturan dan pengawasan berintegrasi kepada seluruh aktivitas di zona pelayanan keuangan dilaksanakan oleh negara-negara Skandinavia sekitar tahun 1980-an. Selain itu, Inggris menerapkan sistem pengawasan terintegrasi pada tahun 1998 melalui pembentukan Otoritas Pengawas Keuangan Inggris, dan juga Jepang pada tahun 1998 dengan pembentukan Otoritas Pengawas Keuangan (OJK) yang juga mengintegrasikan guna pengawasan sektor pelayanan keuangan. Sebaliknya Australia sudah mendirikan Australian Prudential Regulation Authority (APRA) yang mempunyai fungsi yang serupa dengan FSA.

Dalam proses pengawasan membutuhkan adanya kontrol supaya tujuan yang dikehendaki serta aturan yang sudah ditetapkan tidak mengalami penyimpangan, serta berdasarkan peraturan yang sudah ditentukan. Pengawasan pula merupakan emendasi serta koreksi tujuan serta ketentuan yang sepanjang ini diidentifikasi menyimpang. Begitu juga dalam Islam, pengawasan dilakukan agar badan finansial yang diatur tidak melanggar prinsip Islam serta senantiasa bekerja sesuai dengan syariah. Kedudukan OJK dalam mencegah pelanggaran binis investasi sebenarnya sudah dilakukan pada zaman Rasulullah SAW dalam pendekatan hukum ekonomi syariah, hal itu hadir dalam sejarah ekonomi Islam, khususnya pada masa Nabi Muhammad SAW. Ada lembaga bernama Al Hisbah (Musharraf) yang misi utamanya 
mengimplementasikan Ammar Makrouf Nahi Munkar di bidang keuangan. Hisbah tidak hanya membawahi pasar (ekonomi) tapi juga bidang hukum.

\section{Sistem Pengawasan Hisbah}

Terdapat 2 tipe pengawasan yang menjadi kewajiban badan Hisbah:

a. Pengawasan yang bertabiat biasa, seperti seluruh pandangan kehidupan yang berhubungan dengan penerapan kebajikan (al- amru bi al- ma' rûf) serta menghindari kemungkaran (annahyi' an al- munkar).

b. Pengawasan yang bertabiatkhusus, merupakan peengawasan yang berhubungan dengan kegiatan pasar, mencakup perindustrian serta perdagangan; yang berhubungan dengan administratif serta perawatan mutu dan standar produk.

1) Melaksanakan kir dengan cara teratur kepada dimensi, dosis serta timbangan.

2) Melindungi mutu benda.

3) Melindungi kejujuran serta kesamarataan untuk masing- masing bisnis.

4) Melindungi kesetabilan harga.

5) Apabila dikira wajib, muhtasib hendak mengatur harga.

Berdasarkan analisis penulis, detail kewajiban pengawasan pada badan Hisbah merupakan pandangan penangkalan. Hadits yang diriwayatkan oleh Abu Hurairah dalam kasus Nabi Muhammad SAW yang dengan keras menegur pedagang makanan, sebagaimana disebutkan di atas, menjadi argumentasi yang kuat atas anggapan tersebut.

\section{Hisbah Era Rasulullah dengan Hisbah di era Modern}

Dalam sistem ekonomi Islam, pasar diawasi oleh suatu badan yang diketahui dengan julukan gubernur Hasbah, merupakan badan yang dibangun oleh penguasa khusus untuk memantau pasar. Dengan cara historis, bakal anak Hisbah telah terdapat sejak era Rasul. Perihal ini dibuktikan dengan banyaknya riwayat, kalau Rasulullah SAW melaksanakan fungsienumerasi dengan memantau langsung pasar, hasilnya tidak terdapat bentuk kebohongan yang dapat mendatangkan mudarat bagi pihak lain. Al-Hisbah diletakan langsung pondasinya oleh Rasulullah S. A. W., beliaulah Muhtasib (orang yang memantau) awal dalam Islam, seringkali Rasulullah masuk ke pasar Madinah untuk memantau kegiatan jual beli.

Pada era modern, kedudukan hisbah negeri harus menunjuk perseorangan ataupun sekelompok orang, atau yang dapat disebut dengan Daulat Pelayanan keuangan yang akan melaksanakan hisbah tersebut. Di era Rasul, orang yang ditunjuk untuk mengatur Hisbah disebut Al- Mahtis. Al-Mahtis wajib memiliki kualifikasi khusus untuk membenarkan kalau ia sanggup melaksanakan tugasnya sesuai dengan hukum Islam. Patokan yang sangat berarti untuk al- Muhtasib yaitu: kejujuran serta ketidakberpihakan, wawasan serta kebijaksanaan, kesamarataan, kejelasan, kehatihatian, serta tidak mudah tersinggung. Sebab tujuan Hisbah merupakan yaitu untuk mencegah badan warga dari penyimpangan, melestarikan agama mereka, serta 
menjamin keselamatan orang di bumi ini sesuai dengan ketentuan Tuhan Yang Maha Esa.

Oleh sebab itu, aspek Hisbah paling utama berhubungan dengan melindungi ketetapan Tuhan dari pelanggaran, mencegah serta meluhurkan orang, serta membenarkan keamanan warga. Dengan kata lain hisbah merupakan pemeriksaan yang dibentuk oleh Islam untuk melindungi keamanan kehidupan bermasyarakat, agar setiap orangterjamin keselamatannya dan terpenuhi kebutuhannya.

Walaupun UU No. 21 Tahun 2011 mengenai OJK kata "Syariah" hanya terdapat pada Bab 1 Pasal 1 bagian 5. Akan tetapi, kata "syariah" tersebut menjadi landasan hukum bagi OJK untuk mengawasi pelayanan keuangan konvensional dan pelayanan keuangan Islam. Di samping itu juga apabila berkaitan dan berhubungan dengan pengawasan dalam Islam yang sesuai dengan tujuan serta kedudukan alhisbah sebagaimana yang dilaksanakan atau diterapkan oleh Rasulullah SAW. Pengembangan pelayanan badan finansial syariah tersebut sangat berarti sebagai landasan untuk melakukan pengawasan yang berdasarkan pada kepercayaan, terpeliharanya ekonomi yang jujur, seimbang serta berakhir pada akuisisi profit yang seimbang.

\section{Perbedaan Hisbah dengan Otoritas Jasa Keuangan (OJK)}

Pelembagaan etika bidang usaha ini sebetulnya sudah terdapat sejak era 14- 15 , kemudian, paling utama di bumi bidang usaha kalangan muslimin pada saat itu. Di era kemajuan Islam di Madinah (622- 632 M) di mana Rasul Muhammad SAW menjadi pemimpinnya, tela terbentuk sebuah institusi yang disebut hisbah. Hisbah merupakan institusi yang bekerja mengendalikan etika warga dalam kehidupan religiusitas, sosial serta ekonomi. Hisbah diatur oleh aparat yang mempunyai integritas serta daya yang sangat terpercaya serta ahli. Orang yang melakukan kewajiban hisbah disebut dengan Muhtasib. Pada era itu, Rasul Muhammad SAW ialah orang yang menjadi Muhtasib awal di Madinah. Bagaikan Muhtasib yang awal, Rasul Muhammad SAW sudah menaruh pondasi untuk penguatan etika warga. Dia membuat sesuatu gedung etika serta perangkatnya untuk dijadikan ketentuan bermain dalam kehidupan sehari-hari tercantum dalam aktivitas bidang usaha serta ekonomi. 28

Di Indonesia salah satu lembaga yang menyerupai badan Muhtasib di zona badan finansial syariah yaitu Otoritas Jasa Keuangan (OJK). UU. No 21 tahun 2011 menyebutkan bahwa Otoritas Jasa Keuangan (OJK) berperan menyelenggarakan sistem pengaturan serta pengawasan yang berintegrasi kepada totalitas aktivitas di

\footnotetext{
28 Al-Shaykh al-Imam Ibn Taymiya. (1982). Public Duties in Islam, The Institution of the Hisba,
} diterjemahkan oleh Muhtar Holland, The Islamic Foundation, London, hal. 47. 
dalam zona pelayanan keuangan yang mencakup aktivitas pelayanan keuangan di zona Perbankan; aktivitas pelayanan keuangan di zona Pasar Modal; serta aktivitas pelayanan keuangan di zona Perasuransian, Anggaran Pensiun, Badan Pembiayaan, serta Badan Pelayanan keuangan Yang lainnya.

\section{Aspek Hisbah Yang Dapat Diadopsi Otoritas Jasa Keuangan (OJK)}

Dalam perspektif global, globalisasi dan pasar bebas menjadi hal penting yang diasumsikan dapat meningkatkan pertumbuhan ekonomi, sehingga moralitas perilaku pasar yang diimplementasikan melalui etika bisnis menjadi aspek yang dominan dalam mewujudkan keadilan pasar. Dalam hal ini, epistemologi tauhidi memberikan landasan filosofisnya berupa prinsip tauhid, rububiyah, khilafah, tazkiyah, dan akuntabilitas, yang dapat membentuk moralitas perilaku pasar berupa bertindak dengan jujur dan benar, bertindak sederhana dalam hidup, tidak bertindak curang dan menipu dalam bisnis, sekaligus pula menghindari diri dari tindakan ihtikar, tas'ir, riba, tadlis, jual beli gharar, dan tindakan melambungkan harga. Hal-hal itulah yang diterapkan Rasullullah SAW pada badan hisbah dapat diadopsi oleh lembaga Otoritas Jasa Keuangan (OJK) untuk memberikan pengawasan pelayanan jasa keuangan di Indonesia dengan lebih baik seperti yang dicontohkan oleh Rasulullah SAW.

\section{Hisbah dalam Konteks Makro dan Mikro Ekonomi}

Fungsi hisbah serta wewenangnya sangat mendekati dengan yang dilakukan oleh lembaga Otoritas Jasa Keuangan (OJK). Tetapi pada era itu aktivitas dan badan finansial tidak sekompleks saat ini. Dalam kedudukannya, hisbah berfungsi dalam perekonomian bukan hanya sebagai pengawas tetapi juga membuat regulasi, membagikan nasehat (bimbingan serta uraian) dan melaksanakan penindakan dalam perihal membagikan ganjaran dan menjatuhi ganjaran bila terdapat yang melaksanakan aktivitas yang menyimpang dalam perekonomian. Dalam kedudukannya hisbah tidak hanya memantau banyak orang yang melaksanakan perekonomian saja, tetapi memantau warga yang menjadi tanggungjawabnya. Membagikan proteksi yang serupa pada warga supaya warga merasa nyaman dan tidak terdapat kesenjangan di dalam warga dalam perlindungan di zona perekonomian.

Ada pula dalam perihal metode pasar, ekonomi Islam juga mempunyai rancangan tertentu yang mengembangkan prinsip syariah dalam wujud nilai- nilai yang dapat dikategorikan dalam 2 perspektif yaitu makro dan mikro. Andil ekonomi Islam dalam metode pasar ditaksir sangat berarti sebab ekonomi Islam dapat beramal kedudukan yang besar di tengah ketidakstabilan situasi perekonomian bangsa indonesia dikala ini. Angka syariah dalam prespektif mikro menekankan pandangan kompetensi atau profesionalisme serta tindakan tepercaya, sebaliknya dalam prespektif besar nilai- nilai syariah menekankan pandangan penyaluran, pelarangan riba serta aktivitas ekonomi yang tidak membagikan kegunaan dengan 
cara jelas pada sistem perekonomian. Oleh sebab itu, kegunaan sistem perekonomian Islam dalam pasar tertuju tidak hanya pada pemeluk Islam, melainkan pada semua orang. ${ }^{29}$

\section{Implementasi Hukum Ekonomi Islam Melalui Hisbah}

Keberadaan badan hisbah ini dapat diimplementasikan dalam wujud lembagalembaga penguasa di aspek ekonomi serta politik atau badan ekonomi bumi yang berfungsi menjamin terciptanya kesamarataan pasar dengan memantau para pelaku pasar dari seluruh perbuatan kesalahan ekonomi baik dalam rasio nasional ataupun global. Kasus- kasus pencucianuang, perdagangan hitam, traficking, dan hal serupa lainnya menjadi fakta berartinya kehadiran badan hisbah ataupun apapun namanya di masa kesejagatan ekonomi serta pasar leluasa.

Kedudukan terkini yang dicoba penguasa, pada kenyataanya kedudukan pengawasan telah dicoba di era Rasulullah saw. serta telah diatur di dalam QS. AnNisa( 4): 135 yangartinya:

Artinya :"Wahai orang-orang yang beriman, jadilah kamu orang yang benarbenar penegak keadilan, menjadi saksi karena Allah biarpun terhadap dirimu sendiri atau ibu bapak dan kaum kerabatmu. Jika ia kaya ataupun miskin, maka Allah lebih tahu kemashlahatannya. Maka janganlah kamu mengikuti hawa nafsu karena ingin menyimpang dari kebenaran. Dan jika kamu memutar balikan (katakata) atau enggan menjadi saksi, maka sesungguhnya Allah adalah Maha Mengetahui segala apa yang kamu kerjakan."

Ayat tersebut merupakan perintah untuk berlaku adil dalam menegakkan kesamarataan. Jadi penegak kesamarataan yang utuh sesungguhnya menjadi sifat yang menempel pada diri serta dilaksanakan dengan sangat cermat sehingga terlihat totalitas baik lahir ataupunbatin. Jadi pelopor diri sendiri, baik dari orang berumur ataupun kerabat, baik kaya ataupun miskin, situasi yang menjadi alibi untuk tidak melaksanakan kesamarataan. Bagian ini diturunkan saat Rasulullah saw. Di hadapan perkara itu, terdapat 2 orang, satu kaya serta satu lagi miskin, sebagai hati Rasulullah semoga Tuhan memberkati dan memberinya damai, cenderung membela orang miskin karena kasihan atas kemiskinannya.

Dalam perspektif Islam, perlindungan pelanggan serta warga wajib dicoba dengan tujuan membenarkan apa yang salah, membenarkan kekeliruan, serta membenarkan apa yangbenar. Hal ini dapat dilaksanakan bila OJK berpedoman pada Q. S An-Nisa: 135. Tidak hanya itu perlindungan pelanggan serta warga di dasarkan pada rasa khawatir kepada Tuhan, tidak hanya negeri ataupun penguasa.

Sebab dengan melaksanakan ini, pembelahan serta perlindungan menjadi aman. Sebab dalam medukung kesamarataan dalam perihal ini OJK sebagai penanggung jawab penguatan kesamarataan di zona pelayanan keuangan wajib benar-benar bertanggung jawab untuk meluruskan kesamarataan kembali. Tidak

29 Wulandari, et.all. (2020). Tinjauan Islam terhadap Mekanisme Pasar dan Penanganan Distorsinya. Journal of Islamic Economics and Finance Studies, 1(1), hal. 82 - 99. 
hanya berbisnis serta seimbang kepada pelanggan seperti konsumen pelayanan keuangan yang diawasi oleh OJK, tetapi proteksi juga wajib diserahkan pada banyak orang yang terjebak permasalahan pemodalan ini. Dengan terdapatnya rasa khawatir kepada Allah serta terdapatnya agunan pertemuan, sehingga terwujud kesamarataan dan kenyamanan hati karena sesuai dengan determinasi syariah, alhasil pada kesimpulannya fungi OJK ialah melangsungkan sistem yang saling berkaitan dengan semua aktivitas untuk mengawasi serta mengatur pada sektor finansial agar nantinya dapat tercapai.

Sedangkan, Indonesia pada mulanya mempraktikkan sistem pengawasan di sektor pelayanan keuangan yang dilaksanakan melalui institusi, berganti menjadi sistem pengawasan yang berintegrasi kepada seluruh kegiatan yang di dalam zona pelayanan keuangan oleh satu institusi setelah lahirnya “ UU No 21 Tahun 2011 mengenai Daulat Pelayanan keuangan" ("UUOJK") yang legal bertepatan pada 22 November 2011. Dengan itu pengawasan seluruh zona pelayanan keuangan yang terdapat di Indonesia dilaksanakan oleh isntitusi sendiri, yakni "Otoritas Jasa Keuangan" (“OJK"). ${ }^{30}$

Oleh karena itu, pengawasan OJK perlu diintegrasikan secara optimal, agar tujuan pengawasan dapat tercapai. Pengawasan lembaga pelayanan keuangan pada prinsipnya dibagi atas 2 tipe, yaitu pengawaasan dalam bagan mendesak badan itu untuk turut mendukung kemajuan ekonomi serta melindungi kemantapan moneter (macro- economic supervision), serta pengawasan yang mendesak supaya badan pelayanan keuangan dengan cara seorang senantiasa sanggup menjaga kebutuhan warga dengan baik (prudential supervision).

\section{Kesimpulan}

Hisbah adalah lembaga yang bertanggung jawab untuk mengendalikan etika warga dalam kehidupan berkeyakinan, sosial serta ekonomi. Hisbah diatur oleh aparat yang mempunyai integritas serta keahlian. Di Indonesia, salah satu badan yang menyerupai badan muhtasib di zona badan finansial syariah pada masa era Rasulullah SAW yaitu Lembaga Otoritas Jasa Keuangan (OJK). Kedudukan OJK dibentuk untuk menjadi pelayanan keuangan yang mampu mengawasi aktivitas pelayanan keuangan bank maupun non bank, sehingga salah sayunya mampu mencegah adanya fraud pada bisnis investasi. Kedudukan pengawasan yang diperankan oleh OJK telah terdapat sejak era Rasulullah SAW yaitu Badan Hisbah yang berfungsi sebagai pengawas badan finansial Islam, badan finansial Islam mempunyai fungsi sebagai pengawas yakni mengawasi tatanan kehidupan berekonomi dengan cara memberikan aturan hukum yang baik dan benar sesuai dengan syariat Islam. Seperti membenarkan apa yang tidak benar dan mengoreksi

\footnotetext{
${ }^{30}$ Nasution, B. (2014). Struktur Regulasi Independensi Otoritas Jasa Keuangan. Jurnal Hukum dan Peradilan, 3(3), 281-294.
} 
mengoreksi yang salah. Pengawasan oleh badan tersebut harus didasarkan pada rasa takut kepada Tuhan Yang Maha Esa.

\section{Daftar Pustaka}

Arliman, L. (2018). Andil Metodologi Riset Hukum Di Dalam Kemajuan Ilmu Hukum Di Indonesia. Soumatera Law Review, 1 (1), 112- 132.

Arsil. (2013). Memerangkap Pemodalan Bodong dengan Perbuatan Kejahatan Perbankan. Jakarta: Badan Amatan Pembelaan buat Indenpedensi Peradilan.

Atmasasmita, Romli. (2010). Kesejagatan dan Kesalahan Bidang Usaha. Cetakan 1. Jakarta: Prenamedia Tim.

Bungin, B. (2019). Metodologi Riset Kualitatif: Aktualisasi Metodologis Ke Arah Macam Versi Kontemporer.

Cowan, Meter. (1974). A Dictionary of Modern Written Arabic. Beirut: Librairie du Liban.

Fadlia, D. H., \&; Yunanto, Y. (2015). Kedudukan Daulat Pelayanan keuangan (OJK) Dalam Proteksi Hukum Untuk Penanam Modal Atas Asumsi Pemodalan Delusif. Law Reform, 11 (2), 207- 215.

Finansial, O. J. (2015). Daulat Pelayanan keuangan. Keselamatan, 4 (2), 153- 166.

Firmansyah, I. (2014). Determinant of non-performing loan: The case of Islamic bank in Indonesia. Jurnal Ekonomi Moneter serta Perbankan, 17 (2), 241- 258.

Hadad, Meter. D. (2016), Informasi Kemampuan Daulat Pelayanan keuangan. Informasi Kinerja: OJK.

Haikal, S. (2019). Weak, Permissive and Error- Tolerant Supervision: Starting From Correction Habits to Acquit et de Charge Trap As an Entrance to Capital Market Scandal. Asia Pacific Fraud Journal, 4 (1), 78- 95.

Harjono Dhaniswara, K. (2007). Hukum Penanaman Modal.

Haryani, W. S. (2012). Kedaulatan Daulat Pelayanan keuangan dalam Persepektif Hukum No 21 Tahun 2011 mengenai Daulat Pelayanan keuangan. Harian Legislasi Indonesia, 9 (3).

Hasan Shadily, dkk. (2011). Hukum Pemodalan serta Pasar Modal. Jakarta: Cahaya Ilmu.

Hayati, M. Investasi dalam Perspektif Ekonomi Islam. Jurnal Ekonomi dan Bisnis Islam, hal. 67.

Hermansyah. (2005). Hukum Perbankan Nasional Indonesia. Jakarta: Emas Prenada Alat Group.

Islahi, A.A. (1980). Economic Concepts of Ibn Taimiyah. Aligarh: Mukmin Universiti Aligarh.

Juliana, Meter. D. (2015). Wewenang Daulat Pelayanan keuangan Hal Proteksi Hukum Untuk Penanam modal kepada Aksi Tippee Yang Melaksanakan Insider Trading Dalam Perdagangan Saham. Harian Magister Hukum Udayana, 4( 
2), 44146 .

Keagungan, R. F. (2014). Negative Investement: Kunci Menjauhi Kesalahan dalam Bumi Pemodalan. Jakarta: PT. Elex Alat Komputindo.

Krishna, A., Rofaida, R., \& Ekstrak, Meter. (2010). Analisa Tingkatan Literasi Finansial Di Golongan Mahasiswa Serta Faktor- Faktor Yang Mempengaruhinya (Survei pada Mahasiswa Universitas Pembelajaran Indonesia). Proceedings of The 4th International Conference on Teacher Education 4(1), 552- 560.

Marzuki. (1983). Metodologi Studi. Yogyakarta: PT Hanindita Offset.

Mochtar, Z. A.\& Satriawan, I. (2008). Sistem Pemilahan Komisioner State Auxiliary Bodies (Sesuatu Memo Analisa Komparatif). Harian Konstitusi Pusako Universitas Andalas, 1 (1), 85- 106.

Mustaqim, A. H. (2010). Daulat Pelayanan keuangan Bagaikan Pemecahan Sistem Ekonomi Nasional. Harian Perspektif, 8 (1).

Nasution, B. (2014). Bentuk Regulasi Kedaulatan Daulat Pelayanan keuangan. Harian Hukum serta Peradilan, 3 (3), 281- 294.

Otoritas Jasa Keuangan. (2016). Buku Saku Otoritas Jasa Keuangan. Jakarta :OJK, hal. 322-323.

Pardiansyah, E. (2017). Pemodalan Dalam Perspektif Ekonomi Islam: Pendekatan Teoritis Serta Empiris. Economica: Harian Ekonomi Islam, 8 (2), 337- 373.

Profit, B. (2011). Novel Pintar Pemodalan. Yogyakarta: CV. Andi Offset.

Samsul, I. (2016). Proteksi Pelanggan Pelayanan keuangan Sesudah Pembuatan Daulat Pelayanan keuangan (OJK). Jakarta: OJK.

Sinaga, R. D., Nasution, B \&; Siregar, Meter. (2013). Sistem Koordinasi antara Bank Indonesia serta Daulat Pelayanan keuangan dalam Pengawasan Bank sehabis Lahirnya Hukum No 21 Tahun 2011 Mengenai Daulat Pelayanan keuangan. Transparency Journal of Economic Law, 1(2).

Sitompul, Z. (2002). Mungkin Aplikasi Umum Banking System di Indonesia: Amatan dari Perspektif Bank Syariah. Harian Hukum Bidang Usaha, 20(1-9).

Sitompul, Z. (2004). Menyongsong Kedatangan Daulat Pelayanan keuangan (OJK). Harian Pilars, 7(2).

Sundari, S. (2011). Informasi Kompendium Hukum Aspek Perbankan. Jakarta: Kementrian Hukum serta HAM RI.

Sutedi, A. (2014). Pandangan Hukum Daulat Pelayanan keuangan. Suku Bangsa.

Tarina, D. D. Y.; Hutabarat, S. Meter. D. (2020). Supervision of Investment Companies in the Prevention of Illegal Investment Practices. International Journal of Multicultural and Multireligious Understanding, 7 (4), 215- 224.

Widyawati, I. (2012). Faktor- faktor yang pengaruhi literasi keuangan mahasiswa fakultas ekonomi serta bidang usaha Universitas Brawijaya. Assets: Harian Akuntansi serta Pembelajaran, 1 (1), 89- 99.

Wulandari, et. all. (2020). Kajian Islam kepada Metode Pasar serta Penindakan 
P-ISSN: 2746-0967, E-ISSN: 2721-656X

Distorsinya. Journal of Islamic Economics and Finance Studies 1(1), 82- 99.

Yuliana, I. (2010). Pemodalan Produk Finansial Syariah. Jakarta.

\section{Peraturan Perundanga-Undangan}

Undang-undang No. 21 Tahun 2011 Tentang Otoritas Jasa Keuangan. 